\title{
Futuristic Urbanism- Integrating Farming into Urban Landscape for Sustainable Development
}

\author{
Bhagyalaxmi Madapur, Shanu Raina, Reshmi Manikoth Kollarath
}

\begin{abstract}
Unscientific urban expansion and the resulting population growth is phenomenally changing the landscapes of cities and presenting critical challenges. Unplanned urban growth is placing ever increasing demands for better liveable conditions related to housing, transportation, water, food, energy, employment, social infrastructure amenities, etc. As a result, most of the urban areas, transition areas and ru-urban fringe areas are witnessing steady increase in the conversion of farming land leading to degradation of the urban environment while creating food security concerns. Food demands of urban areas are traditionally supported by their hinter lands and surrounding rural areas. Majority of urban area's food equivalences are affected by its multi-cultured social fabric implying that the demand for food is diverse. Against this background, this paper analysis the correlation between urban farming and supporting the food demands in urban areas. Further paper discusses critical challenges and various potential opportunities available for promoting urban farming as a significant tool in encouraging balanced sustenance of urban areas through proactive and innovative methods.
\end{abstract}

Keywords - Urban farming, Food security, Urban expansion, Urban landscape, Sustainable urban development, Futuristic urbanism

\section{INTRODUCTION}

Unscientific urban expansion and the resulting population growth (the total urban population is projected to reach 7.5 billion by 2050) is phenomenally changing the landscapes of cities and presenting critical challenges. Taking the cognisant of the situations that prevail in the contemporary cities, it can be visualised that the cities in future will be far more diverse in their socio-cultural and economical domains. Unplanned urban growth is placing ever increasing demands for better liveable conditions related to housing, transportation, water, food, energy, employment, social infrastructure amenities, etc. As a result, most of the urban areas, transition areas and ru-urban fringe areas are witnessing steady increase in the conversion of farming land leading to degradation of the urban environment while creating food security concerns. Food security is associated with the need for stable, accessible and nutritious food services. As a major consequence of food insecurity and subsequently inadequate nourishment is bound to result in chronic public health issues. Inadequate nourishment is not only associated with food insecurity but lack of accessibility to healthy food in neighbourhoods especially those

Revised Manuscript Received on July 10, 2019.

Bhagyalaxmi Madapur, Architecture , BMS College of Architecture, Bangalore, Karnataka, India (E-mail: bhagya.chandgude@gmail.com)

Shanu Raina, Architecture, BMS College of Architecture, Bangalore, Karnataka, India. (E-mail: raina.architect@gmail.com)

Reshmi Manikoth Kollarath, Architecture, BMS College of Architecture, Bangalore, Karnataka, India (E-mail: reshmimk@gmail.com) comprised of diverse mix of urban communities. In view of the increasing pr ice of food owing to the extreme climatic conditions, Food and Agricultural Organization of United Nations (FAO), urban and peri-urban agriculture has been recognized as a farming system primarily contributing to food security and generation of employment while improving the urban ecology to achieve sustainable urban development.

\section{FOOD ISSUES IN URBAN AREAS}

\section{A. Urbanization and the prevailing adverse conditions}

Rapid urbanization process is creating enormous demands for land to accommodate the growth. In the process, huge tracts of fertile farming lands are being developed irrationally leading to food and water crisis severely impacting the urban environment and health of the urban communities. The constant reduction in the arable land is posing threat for the urban bio-diversity. These adverse conditions are further aggravated by the additional demands for energy and water presented by urbanization.

\section{B. Corelation between multi-ethnicity and food demand}

Majority of urban area's food equivalences are affected by its multi-cultured social fabric implying that the demand for food is diverse. Cosmopolitan flavor of the cities coupled with the increased income levels and the subsequent unrestricted spending has been transforming food for many urban dwellers into something more than just the sustenance. But in comparison with the other key components of the city building, the profound information and understanding about the food supply-demand system is highly neglected in urban design, planning and policy discourses.

\section{Food demand and supply crisis}

Increased urbanization, population, migration, high transportation costs, adverse climatic conditions, etc. are potentially impacting the ever-increasing cost of food. Increasing demand and prices of basic food supplies are not only associated with its availability but to the degree of accessibility and right utilization of the available food comprised of affordability, nutrition levels of food as well as food security. Systems of food production and consumption are majorly influenced by the access to quality food and the resulting public health.

\section{Published By:}

Blue Eyes Intelligence Engineering \& Sciences Publication 


\section{FUTURISTIC URBANISM- INTEGRATING FARMING INTO URBAN LANDSCAPE FOR SUSTAINABLE DEVELOPMENT}

\section{URBAN FARMING}

\section{A. Cites and farming}

A detailed perceptive analysis of the origins of the human settlements reveals the fact that although they were established at strategic locations, they essentially require a fertile land to sustain and meet their food demands. Historically, urban areas have been the epicenters of farming innovations. The settlements grow and thrive as the cosmopolitan metropolis due to the availability of the most fertile lands as well as productive plains. This aspect highlights the correlation between natural and manmade environment in turn stimulating the urbanization. However, unfortunately owing to the adverse changes (socio-economic and environmental) this cohesive correlation is getting disconnected. In the present scenario, cites, across the globe are perceived as solids with built environment. Hence, urban areas and farming are particularly visualized as conflicting activities.

Food demands of urban areas are traditionally supported by their hinter lands and surrounding rural areas. As the cities grow, the food and the nutritional demands of the increasing population needs to be addressed through proactive and innovative methods. Urban dwellers have limited access and control over the food they consume. Increasing living costs, land prices, transportation costs, labor costs coupled with severe climatic conditions directly influence the quality, quantity and supply of the food. In such scenario, urban farming is not only the most viable solution to address the growing food demands in an ethical way but also to generate related socio-economic and ecological benefits. Following table summarizes the benefits of urban farming in different domains (Refer Table I).

Table I. Urban Farming - Benefits Of Urban Forming In Different Domains

\begin{tabular}{|c|c|c|}
\hline Sl.no. & Domains & Remarks \\
\hline 1 & Ecological & $\begin{array}{l}\text { Protection of hinterland, opportunities for organic farming, effective } \\
\text { management of natural resources (open spaces, vacant lands, degraded } \\
\text { land areas, water shed areas, wetlands, etc.), reduction in food miles, } \\
\text { controlling pollution \& degradation of land, etc. }\end{array}$ \\
\hline 2 & Social & $\begin{array}{l}\text { Urban farming can be versioned as a form of public space for active } \\
\text { involvement in turn enhancing the food security of the community. } \\
\text { Endless possibilities for engaging urban dweller's interest in active work, } \\
\text { recreation and regenerative activities there by contributing to the physical } \\
\text { and mental wellbeing. }\end{array}$ \\
\hline 3 & Economic & $\begin{array}{l}\text { Employment \& income generation, balanced equation of supply-demand, } \\
\text { reduction in food costs as food miles are nominal, etc. }\end{array}$ \\
\hline
\end{tabular}

\section{B. Urban farming - Analysis of potential locations}

Urban areas do have enormous potential for growing their own food despite of greater densities. Metropolitan areas expand primarily as four distinctive zones; core, wedge, corridor and periphery having dense, mixed use, patchy and ever changing peripheral conditions respectively while influencing the intensity and the type of land use. Thus farming options differ to a great extent and has a particular character derived from the nature of the zone. The four-zone model can be used to analyze the locations of urban farming along with the scope, despite the exceptions and the fast dissolving boundaries between urban and rural areas (Refer Table II).

Table II The four-zone model to locate the urban farming areas and types

\begin{tabular}{|c|c|c|c|}
\hline Sl. no. & Domains & Character of the area & Urban farming locations and scope \\
\hline 1 & $\begin{array}{l}\text { Core (center \& } \\
\text { nodes) }\end{array}$ & $\begin{array}{l}\text { Highest density } \\
\text { (Population \& built form) }\end{array}$ & $\begin{array}{l}\text { Locations: } \\
\text { Redevelopment \& vacant plots (for temporary use), } \\
\text { public parks, unbuildable areas, water front areas, water } \\
\text { bodies, rooftops, balconies, etc. } \\
\text { Scope: } \\
\text { Small scale plastic greenhouse farming systems } \\
\text { including hydroponics for crops with higher value }\end{array}$ \\
\hline 2 & Wedge & High to medium density & $\begin{array}{l}\text { Locations: } \\
\text { Zones wedged between districts, Wedges between } \\
\text { corridors \& periphery, steep unbuildable areas (steep } \\
\text { slopes, river edge, wetlands), military bases, university } \\
\text { campuses, solid waste dumps, cemeteries, etc. } \\
\text { Scope: } \\
\text { Orchards, fish ponds, milk production, poultry \& egg, } \\
\text { etc. }\end{array}$ \\
\hline
\end{tabular}




\begin{tabular}{|l|l|l|l|}
\hline \multirow{3}{*}{3} & & $\begin{array}{l}\text { Locations: } \\
\text { Along main corridors, transportation networks linked to } \\
\text { commercial/residential areas, corridor farming with }\end{array}$ \\
& Corridor & Medium to lower density \\
& & $\begin{array}{l}\text { Scope: } \\
\text { Sctail outlets, etc. } \\
\text { Interim farming, pollution resistant \& low-intensity } \\
\text { crops, ornamental horticulture, micro-livestock, grazing, } \\
\text { market gardening, vegetables, flowers, etc. }\end{array}$ \\
\hline 4 & Periphery & $\begin{array}{l}\text { Locations: } \\
\text { Efficiently connected fringe areas, Small \& medium size } \\
\text { farms with favorable landscape features, etc. } \\
\text { Scope: } \\
\text { Intensive vegetable production, higher value crops, } \\
\text { agro-forestry providing firewood, timber, resin, etc. }\end{array}$ \\
\hline
\end{tabular}

\section{RESULTS \& DISCUSSIONS}

Analysis of urban ecological footprint reveals the crucial aspect that every category of material and energy consumption and disposal of generated waste requires the productive / absorptive capacity of a finite area of land and water. Growing competing demands on natural resources have been increasingly challenging long-term sustainability and socio-economic equity.
Supply of food to urban areas is an important component of the ecological footprint of urban areas. Urbanization is interconnected with the locations of food production. Different urban farming systems require different types of urban spaces. These spaces include community lands, public parks, areas allocated for other uses such as area along the streets, areas unfit for building activities such as wetlands, steep terrain, buffer areas of infrastructure facilities, water bodies, flood plains and spaces inside, on and around the buildings (Refer Table III).

Table III Urban Farming- Potential Integrations For Built And Natural Environment

\begin{tabular}{|c|c|c|}
\hline Sl.no. & Type of space & Description \\
\hline 1 & $\begin{array}{l}\text { Inside, on and around the } \\
\text { buildings }\end{array}$ & $\begin{array}{l}\text { Buildings with front, back and side yards } \\
\text { Rooftops, vertical surfaces such as (facades, walls, etc.) balconies, patios of } \\
\text { buildings in dense cities that do not have the yard space. } \\
\text { Advantages: } \\
\text { Comparatively secured tenure of the land, no commuting time, availability of } \\
\text { vital resources, etc. }\end{array}$ \\
\hline 2 & Community spaces & $\begin{array}{l}\text { Community spaces can be promoted as community gardens for farming in a } \\
\text { cooperative way in which community gardeners (participants) cultivate in } \\
\text { their own plots individually but share common facilities such as supply of } \\
\text { resources, operation, maintenance and security. } \\
\text { Community farming areas can also act as center of social interaction having } \\
\text { institutional, locational and social characteristics. }\end{array}$ \\
\hline 3 & Neighbourhood & $\begin{array}{l}\text { Completely and partially built neighborhoods support horticulture without } \\
\text { soil and small-scale livestock production. It is also one of the most efficient } \\
\text { infrastructures to weave a cohesive community. }\end{array}$ \\
\hline 4 & Urban waste lands & $\begin{array}{l}\text { Government and private agencies with the help of NGOs can involve the } \\
\text { community in transforming urban wastelands into urban farming plots that } \\
\text { are irrigated with waste water meanwhile improving the ecological } \\
\text { conditions of the urban areas. } \\
\text { They can also have significant positive impacts on the urban area's waste } \\
\text { water and drainage system and making productive use of marginal strips of } \\
\text { land areas located adjacent to canals, culverts, storm water channels, etc. }\end{array}$ \\
\hline 5 & Steep terrains & $\begin{array}{l}\text { Steep terrains present numerous challenges for building activities. hence, } \\
\text { present diverse opportunities for urban farming. }\end{array}$ \\
\hline
\end{tabular}


FUTURISTIC URBANISM- INTEGRATING FARMING INTO URBAN LANDSCAPE FOR SUSTAINABLE DEVELOPMENT

\begin{tabular}{|c|c|c|}
\hline 6 & $\begin{array}{l}\text { Flood plains and streamside } \\
\text { areas }\end{array}$ & $\begin{array}{l}\text { Flood plains and streamside present most appropriate sites for urban farming } \\
\text { as they have most fertile soil and access to water. Streamside farming } \\
\text { includes rivers, creeks, canals, etc. Several urban streams mainly in } \\
\text { developing countries are treated as drainage channels or open sewers. Hence, } \\
\text { monitoring is required to prevent food contamination from polluted water. }\end{array}$ \\
\hline 7 & Wetlands and water bodies & $\begin{array}{l}\text { The extremely sensitive wetlands and water bodies within urbanized areas } \\
\text { can be tapped to potentially transform waste water into food for the urban } \\
\text { areas. } \\
\text { Wetlands are needed to conserve and regenerate ecologically vital resources. } \\
\text { Urban farming can be introduced in these areas without much disturbance to } \\
\text { the thriving bio-diversity. }\end{array}$ \\
\hline 8 & Community lands & $\begin{array}{l}\text { Community lands for farming owned by government, para-government } \\
\text { agencies or institutions include areas unsuitable for building activities, areas } \\
\text { reserved for future development, open spaces, parks, vacant lands, etc. } \\
\text { ranging widely in sizes and locations. }\end{array}$ \\
\hline 9 & Areas along the streets & $\begin{array}{l}\text { The long and narrow areas along the streets can be used for urban farming } \\
\text { (either mono-cropped or intercropped). Its locational advantages make it } \\
\text { easier to move the water/fertilizer supplies and marketing of the produce. }\end{array}$ \\
\hline 10 & $\begin{array}{l}\text { Degenerated inner city core } \\
\text { areas }\end{array}$ & $\begin{array}{l}\text { Degenerated inner city core areas can be developed as urban farms modelled } \\
\text { as large-scale greenhouse facilities to promote and retain business and public } \\
\text { activities. They also generate employment for the surrounding } \\
\text { neighborhoods. }\end{array}$ \\
\hline 11 & $\begin{array}{l}\text { Educational institutions as } \\
\text { spaces for community farming }\end{array}$ & $\begin{array}{l}\text { Educational institutions promoted as spaces for community farming with an } \\
\text { objective of improving the nutritional conditions in students. They can also } \\
\text { be used as platforms for creating awareness regarding farming not only to } \\
\text { students but to their families and the community at large while reaping } \\
\text { economic benefits by selling the surplus produce. }\end{array}$ \\
\hline 12 & $\begin{array}{l}\text { Reserved public and private } \\
\text { spaces }\end{array}$ & $\begin{array}{l}\text { Large tracts of reserved public and private open spaces (such as airports, } \\
\text { military bases, ports, hospitals, universities, open spaces, recreational areas, } \\
\text { etc.) as well as brownfield areas can provide significant space for urban } \\
\text { farming. Additionally, they can also gain economic benefits through rents, } \\
\text { lease, etc. }\end{array}$ \\
\hline 13 & Industrial zones & $\begin{array}{l}\text { Manufacturing facilities in industrial zones can also be farmed with } \\
\text { objectives of generating employment, land and water access and food } \\
\text { security for the unskilled workers who subsist on the periphery of the } \\
\text { manufacturing facility without being employed directly. } \\
\text { Advantages: } \\
\text {-Promotes productive utilization of the land while discouraging its invasion } \\
\text { by squatters. } \\
\text {-Industry's treated waste can be converted into inputs for energy and food } \\
\text { production. } \\
\text {-Multiple positive uses of land such as farming selective produce, guarded } \\
\text { forests, beekeeping, breeding tanks for aquatic life, etc. }\end{array}$ \\
\hline 14 & Right-of-way farming & $\begin{array}{l}\text { Right-of-way areas such as railroad tracks, canals, electric power } \\
\text { transmission/ natural gas and utility service networks can be either rented or } \\
\text { leased out for farming for mutual benefits of providing land maintenance, } \\
\text { rental income and lands for farmers who do not have space to farm. }\end{array}$ \\
\hline 15 & Women's Community Gardens & $\begin{array}{l}\text { Special community gardens with an integral link to gender can be extensions } \\
\text { of community kitchens sharing the produce collectively. }\end{array}$ \\
\hline
\end{tabular}

\section{A. Duration of use}

Urban farming activities are significantly influenced by the duration of the time that a particular space is available for farming as it cascades on several other related aspects such as types of crops, amount of planning and preparation. certain important spaces are available either permanently or temporarily (Refer Table IV). 
Table IV Duration Of Different Spaces Available For Urban Farming

\begin{tabular}{|c|c|c|}
\hline Sl. No. & Duration & Types of spaces \\
\hline 1 & Permanent use & $\begin{array}{l}\text { Certain areas such as steep terrains, water bodies, flood } \\
\text { plains, wetlands and streamside are permanently available } \\
\text { for urban farming as they are unsuitable for building } \\
\text { activities. They should be used for urban farming along } \\
\text { with recreational open space activities. }\end{array}$ \\
\hline 2 & Long term use & $\begin{array}{l}\text { Certain urban areas covering large tracts of land are } \\
\text { reserved for eventual non-agricultural uses, but in the } \\
\text { interim such lands can be used for farming, biological } \\
\text { waste processing, ecologically sensitive recreation } \\
\text { facilities, etc. enhancing the environmental balance and } \\
\text { generation of economy. }\end{array}$ \\
\hline 3 & Short term use & $\begin{array}{l}\text { Interim availability of land in tune with the time } \\
\text { encourages urban farming. } \\
\text { As the city grows and expands its perimeter, several plots } \\
\text { are always available for the short-term farming. } \\
\text { Temporary sites are often available for urban farming as } \\
\text { redevelopment activities in the old city cores and } \\
\text { neighborhoods. }\end{array}$ \\
\hline
\end{tabular}

It is imperative for government to create long-term plans for managing several unbuilt and unbuildable lands that are permanently available for urban farming. Urban areas are potential platforms for exploring integration of urban farming with the natural and built environment through various techniques (Refer Table V \& VI).

Table V Different Possibilities For Integrating Urban Farming With The Natural Environment

\begin{tabular}{|c|c|c|c|}
\hline Sl.no. & Urban farming options & Possible settings & Harvests \\
\hline 1 & Agroforestry & $\begin{array}{l}\text { Peripheral areas, green } \\
\text { buffer zones, protected } \\
\text { forest areas, natural parks, } \\
\text { etc. }\end{array}$ & Wood, fuel, compost, building materials, etc. \\
\hline 2 & Horticulture & $\begin{array}{l}\text { Sub-urban areas, open } \\
\text { spaces, natural landscapes, } \\
\text { derelict land, along the } \\
\text { streets, hydroponics, green } \\
\text { houses, etc. }\end{array}$ & All types of green produce, bio-compost, etc. \\
\hline 3 & Aquaculture & $\begin{array}{l}\text { Wetlands, lakes, reservoirs, } \\
\text { drainage basins, sewage } \\
\text { lagoons, canals, etc. }\end{array}$ & All types of green produce, fish, fodder, etc. \\
\hline 4 & Livestock & $\begin{array}{l}\text { Urban fringe areas, greens } \\
\text { along the streets, pens \& } \\
\text { sheds, open grazing areas, } \\
\text { animal farms, etc. }\end{array}$ & Milk products, meat, hides \& skins, manure, etc. \\
\hline 5 & Others & $\begin{array}{l}\text { Urban forest, container } \\
\text { gardening, green houses, } \\
\text { roof tops, etc. }\end{array}$ & Herbs, medicinal plants, flowers, etc. \\
\hline
\end{tabular}

Table IV Different Techniques For Integrating Urban Farming With The Built Environment

\begin{tabular}{|l|l|l|}
\hline \multicolumn{1}{|c|}{ Sl.no. } & \multicolumn{1}{|c|}{ Title } & \multicolumn{1}{c|}{ Description } \\
\hline 1 & $\begin{array}{l}\text { Building Integrated } \\
\text { Agriculture (BIA) }\end{array}$ & $\begin{array}{l}\text { BIA is the practice of integrating high-performance hydroponic greenhouse } \\
\text { systems into the built forms to make use of the synergies between the building } \\
\text { environment and farming like nutrient flows. }\end{array}$ \\
\hline 2 & Vertical farming & $\begin{array}{l}\text { Vertical farming conserves bio-diversity, more productivity per unit of area, } \\
\text { reduction of heat island \& carbon footprint, promotes agro-ecology, facilitates } \\
\text { recycling of organic waste and curbs the energy used for providing food. }\end{array}$ \\
\hline 3 & $\begin{array}{l}\text { Steep terrain as green buffer } \\
\text { zone }\end{array}$ & $\begin{array}{l}\text { Developing steep terrains into green buffer zones stabilizes the slopes, absorbs } \\
\text { air pollution and prevents soil erosion while providing food and job security. }\end{array}$ \\
\hline
\end{tabular}


FUTURISTIC URBANISM- INTEGRATING FARMING INTO URBAN LANDSCAPE FOR SUSTAINABLE DEVELOPMENT

\begin{tabular}{|l|l|l|}
\hline 4 & Aqua-terra farming systems & $\begin{array}{l}\text { Aqua-terra farming systems that combine land and aquatic crops as well as } \\
\text { animal life are most appropriate for floodplains. It also helps in preserving } \\
\text { biodiversity. }\end{array}$ \\
\hline 5 & Sewage-fed lagoon fisheries & $\begin{array}{l}\text { Ecologically sensitive wetlands can be converted into sewage-fed lagoon } \\
\text { fisheries to maintain the wetland habitat. }\end{array}$ \\
\hline 6 & Aqua-culture below the city & $\begin{array}{l}\text { Conceptually aquaculture is sited below the city. Waste water can be directed } \\
\text { downstream to benefit aquatic animal/plant life from its nutrients in turn } \\
\text { purifying the water. }\end{array}$ \\
\hline
\end{tabular}

\section{B. Urban farming - Analysis of case examples}

Several cities in both developed and the developing countries are experimenting with numerous innovative initiatives and programs to promote holistically sustainable urban farming (Refer Table VII).

Table VII Urban Farming-Analysis Of Case Examples

\begin{tabular}{|c|c|c|c|}
\hline Sl.no. & Case examples & Project & $\begin{array}{c}\text { Analysis } \\
\end{array}$ \\
\hline 1 & Canada & Sharing backyard & $\begin{array}{l}\text { This innovative initiative connects owners with parcel } \\
\text { of lands with urban farming enthusiasts. Through } \\
\text { physical mapping of the locations and online portals, } \\
\text { both the parties can connect with each other and farm. }\end{array}$ \\
\hline 2 & Seattle, Washington & $\begin{array}{l}\text { Community farming areas } \\
\text { as center of social } \\
\text { interaction }\end{array}$ & $\begin{array}{l}\text { Community farming areas are promoted as center of } \\
\text { social interaction, }\end{array}$ \\
\hline 3 & New York & $\begin{array}{l}\text { Sustainable Urban } \\
\text { Agriculture Program }\end{array}$ & $\begin{array}{l}\text { Through this program, New York State Energy } \\
\text { Research and Development Authority identifies and } \\
\text { maps available potential open spaces, vacant lands, } \\
\text { community gardens, etc., for urban farming. }\end{array}$ \\
\hline 4 & London & Edible Building & $\begin{array}{l}\text { Edible Building, a program by the organization } \\
\text { SUSTAIN in London promotes food production in } \\
\text { three dimensions of a building- inside, on, walls and } \\
\text { roof. }\end{array}$ \\
\hline 5 & Durgapur, West Bengal & $\begin{array}{l}\text { Enabling Worker's union } \\
\text { for farming }\end{array}$ & $\begin{array}{l}\text { In Durgapur, a planned industrial zone, the plant } \\
\text { managers leased land to the worker's union for } \\
\text { farming and provided access to water reservoir used } \\
\text { to cool the steel. This provision supplemented } \\
\text { workers with food and additional income by farming } \\
\text { at the job site. }\end{array}$ \\
\hline 6 & Singapore & Agro-technology parks & $\begin{array}{l}\text { Singapore has recognized and elevated urban farming } \\
\text { as an industrial activity. Agrotechnology parks set up } \\
\text { by Department of Primary Production are modelled as } \\
\text { industrial parks fitted with parks, hydroponic / } \\
\text { aeroponic farms, fish / poultry farms, etc. }\end{array}$ \\
\hline 7 & Hyderabad & $\begin{array}{l}\text { Urban farming along Musi } \\
\text { river }\end{array}$ & $\begin{array}{l}\text { In this case, people living along Musi river which } \\
\text { flows through the city use the river water for urban } \\
\text { farming and grow produce although this is not } \\
\text { supported by the government. }\end{array}$ \\
\hline 8 & Haiti & CARE- Haiti & $\begin{array}{l}\text { Demonstration gardens, mostly on rooftops has been a } \\
\text { popular initiative in Haiti to promote urban } \\
\text { horticulture in urban, peri-urban, slum areas. It has } \\
\text { also extended the program to include community and } \\
\text { school gardens. }\end{array}$ \\
\hline 9 & Xochimilco, Mexico City & Chinampas, Floating farms & $\begin{array}{l}\text { These floating farms have vegetables, livestock, } \\
\text { poultry, trees for fuel and ornamental plants/flowers } \\
\text { are produced on land that is punctuated by canals that } \\
\text { provide transportation, irrigation, recreation as well as } \\
\text { tourism. }\end{array}$ \\
\hline
\end{tabular}




\begin{tabular}{|l|l|l|l|}
\hline & & & $\begin{array}{l}\text { CONCERN has been working with local citizens to } \\
\text { develop soil conservation and sustainable land-use } \\
\text { techniques through a project that includes } \\
\text { agroforestry, horticulture (fruit trees) and the } \\
\text { construction of non-erodible drains and check dams. } \\
\text { The objectives of this initiative are to improve } \\
\text { farming practices, reduction in urban soil erosion and } \\
\text { practicing ecologically sustainable land-use practices. }\end{array}$ \\
\hline 11 & Ireland & Irish charity CONCERN & $\begin{array}{l}\text { Fertile flood plains of Yamuna river along the } \\
\text { Yamuna river is used extensively for urban farming. }\end{array}$ \\
\hline 12 & Belhi & $\begin{array}{l}\text { Urban farming along the } \\
\text { banks of Yamuna river }\end{array}$ & $\begin{array}{l}\text { A cooperative initiative in which community } \\
\text { gardeners (participants) cultivate in their own plots } \\
\text { individually but share common facilities such as } \\
\text { supply of resources, operation, maintenance and } \\
\text { security. }\end{array}$ \\
\hline \multirow{2}{*}{13} & Nagpur & $\begin{array}{l}\text { Slum dwellers of Nagpur city have initiated organic } \\
\text { farming on the terraces and narrow vacant plots in an } \\
\text { informal way. Along with supporting daily needs, the } \\
\text { surplus produce is sold locally. }\end{array}$ \\
\hline
\end{tabular}

C. Access to land and tenure

Urban farming continues on land and in water under a variety of legal and extra-legal arrangements through ownership, renting, leasing, etc. (Refer Table VIII).

Table VIII Access to land and tenure

\begin{tabular}{|c|c|c|c|}
\hline Sl.no. & Type of arrangement & Description & Remarks \\
\hline 1 & Farming under permit & $\begin{array}{l}\text { Official access to farming on areas such } \\
\text { as rights-of-way, port authorities, etc. } \\
\text { in return for maintenance of land. }\end{array}$ & \multirow{3}{*}{$\begin{array}{l}\text { Favorable arrangements for both } \\
\text { landowners and farmers if tenancy laws } \\
\text { ensure the rights of both. }\end{array}$} \\
\hline 2 & Fiscal rent or lease & $\begin{array}{l}\text { This arrangement provides official } \\
\text { access to the land and pays rent as a } \\
\text { share of income earned through the land. }\end{array}$ & \\
\hline 3 & Usufruct rent or lease & $\begin{array}{l}\text { Official access and rent are based on a } \\
\text { usufruct basis. Examples include lands } \\
\text { around public and private facilities. }\end{array}$ & \\
\hline 4 & Unsanctioned farming & Farming without the owner's consent & \multirow[b]{2}{*}{$\begin{array}{l}\text { Informal /illegals arrangements leading } \\
\text { to squatters. }\end{array}$} \\
\hline 5 & Informal agreements & $\begin{array}{l}\text { Farming with the owner's consent but } \\
\text { without the official agreement. }\end{array}$ & \\
\hline
\end{tabular}

\section{Land ownership and access for farming in urban areas}

Urban areas face the lack of space, land and water bodies to farm. Gaining legal access and secured tenure are the major hurdles to farm the area. Hence, resolving land ownership and acquiring appropriate official arrangements will unlock potential spaces for urban farming (Refer Table IX).

Table IX Land Ownershipand Access For Farming In Urban Areas

\begin{tabular}{|l|l|l|l|l|}
\hline \multirow{2}{*}{ Sl.no. } & \multicolumn{1}{|c|}{ Category } & \multicolumn{1}{|c|}{ Sub-category } & \multicolumn{1}{c|}{\begin{tabular}{c}
\multicolumn{1}{c|}{ Potential for urban } \\
farming
\end{tabular}} & \multicolumn{1}{c|}{ Access } \\
\hline \multirow{2}{*}{1} & \multirow{2}{*}{ Private land } & Owned & High & $\begin{array}{l}\text { Closed and strongly } \\
\text { controlled }\end{array}$ \\
\cline { 3 - 5 } & & $\begin{array}{l}\text { Tenanted (often short } \\
\text { term) }\end{array}$ & Low & $\begin{array}{l}\text { Closed and controlled by } \\
\text { both the owner \& the } \\
\text { tenant }\end{array}$ \\
\cline { 3 - 6 } & Leases (often long term) & Medium & $\begin{array}{l}\text { Closed and controlled by } \\
\text { both owner \& lessee }\end{array}$ \\
\hline 2 & Establishment land & Large premises & $\begin{array}{l}\text { High as excess land can } \\
\text { be farmed }\end{array}$ & $\begin{array}{l}\text { Closed and strongly } \\
\text { controlled }\end{array}$ \\
\hline
\end{tabular}


FUTURISTIC URBANISM- INTEGRATING FARMING INTO URBAN LANDSCAPE FOR SUSTAINABLE DEVELOPMENT

\begin{tabular}{|l|l|l|l|l|}
\hline & Small premises & $\begin{array}{l}\text { Variable as depends on } \\
\text { the availability of excess } \\
\text { area }\end{array}$ & Closed and control varies \\
\hline 3 & Public land & $\begin{array}{l}\text { National/state/city } \\
\text { authorities }\end{array}$ & $\begin{array}{l}\text { High an the vacant spaces } \\
\text { can be farmed }\end{array}$ & $\begin{array}{l}\text { Often open with variable } \\
\text { control }\end{array}$ \\
\cline { 2 - 5 } & $\begin{array}{l}\text { Community land owned } \\
\text { collectively under } \\
\text { customary law or donated } \\
\text { for use of the public }\end{array}$ & $\begin{array}{l}\text { Medium as Collective/ } \\
\text { community farming }\end{array}$ & $\begin{array}{l}\text { Often controlled by } \\
\text { property provisions. }\end{array}$ \\
\cline { 2 - 5 } & $\begin{array}{l}\text { Illegally occupied on } \\
\text { private/public/community } \\
\text { lands }\end{array}$ & $\begin{array}{l}\text { Low unless the tenure is } \\
\text { fairly secured }\end{array}$ & Variable \\
\hline
\end{tabular}

\section{E. Differnt framework to support urban farming}

Urban planners and managers focus and plan the development in terms of transportation, housing, employment, etc. rather than in terms of faming as it relatively generates low returns on investments. Hence, urban farming suffers from a combination of political restraints, restrictive urban policy, indecision about property rights of land, lack of organization/representation of urban farmers.
Ecological footprint of urban areas can be potentially reduced if the agenda of urban farming is combined into a comprehensive urban policy. It is possible to develop policies to reduce environmental impacts and there by depletion of natural resources by establishing the ecological footprint of different consumption patterns, infrastructure and certain densities distinctively (Refer Table X).

Table X Differnt frameworks to support urban farming

\begin{tabular}{|l|l|l|}
\hline \multicolumn{1}{|c|}{ Sl.no. } & \multicolumn{1}{|c|}{ Framework } & \multicolumn{1}{c|}{ Description } \\
\hline 1 & Planning framework & $\begin{array}{l}\text { Planners need to recognize the importance of urban farming and develop } \\
\text { strategies and implementing mechanisms for bringing urban farming in the } \\
\text { main stream to secure self-reliance on food to promote sustainable } \\
\text { development. }\end{array}$ \\
\hline 2 & Policy framework & $\begin{array}{l}\text { Policy and program frameworks to persuade public and private land owners to } \\
\text { make sleeping land / free land either make productive or make them available } \\
\text { for inserted citizens and farmers to be developed as urban farm land. }\end{array}$ \\
\hline 3 & $\begin{array}{l}\text { Community supported } \\
\text { agriculture }\end{array}$ & $\begin{array}{l}\text { This scheme brings growing and consumption in a mutually beneficial } \\
\text { arrangement. }\end{array}$ \\
\hline 4 & $\begin{array}{l}\text { Strong community spirit and } \\
\text { social cohesion }\end{array}$ & $\begin{array}{l}\text { Urban farming for self-consumption and occupation are vital sources of food } \\
\text { security. }\end{array}$ \\
\hline 5 & $\begin{array}{l}\text { Urban farming and food } \\
\text { culture }\end{array}$ & $\begin{array}{l}\text { Integration of urban farming and local food culture into nutrition education } \\
\text { programs. }\end{array}$ \\
\hline 6 & Producer organizations & $\begin{array}{l}\text { Strengthening producer organizations through value-chain development and } \\
\text { increased access to finance. }\end{array}$ \\
\hline 7 & $\begin{array}{l}\text { Climate change strategies and } \\
\text { action plans }\end{array}$ & $\begin{array}{l}\text { Urban area-based climate change strategies and action plans for supporting } \\
\text { urban farming through improved market infrastructure, training and extension } \\
\text { programs }\end{array}$ \\
\hline
\end{tabular}

\section{WAY FORWARD}

Functioning and the relationships with the environment of urban areas are changing while plugging them into an increasingly global hinterland and thus increasing ecological footprint. Ever expanding ecological footprint of urban areas is stretching far beyond its actual physical boundaries and is stamping out the habitat of several species. Hence, management of land becomes more efficient if the urban farming is considered as permitted land use.

Currently, there is a need to recognize that the urban farming is an appropriate permanent and long-term land use. Urban farming contributes to the socio-economic and environmental sustainability of cities. The contributions of farming in urban areas can be measured in terms of environmental conservation and food security, rather than purely as returns on investments. The initiatives on energy efficiency, high resource productivity and strong policies for containing the urban sprawl have greater influence in promoting urban farming as a significant tool in encouraging balanced sustenance of urban areas.

\section{REFERENCES}

1. Acharya,A.,D. Hoornweg and M.Dubbeling. 2011. Urban agriculture is climate-smart: Thinking outside the box on climate change.chapter 7.2 Low carbon cities, World bank publication for the government of China. Washington, DC:World Bank 
2. Comstock, N., et al., Neighbourhood attachment and its correlates: Exploring neighbourhood conditions, collective efficacy, and gardening. Journal of Environmental Pscychology, 2010.30:p.435-442.

3. Corrigan, M.P, Growing what you eat: Developing community gardens in Baltimore, Maryland.Applied Geography. 31(4):p.1232-1241.

4. Ferris,J.,C. Norman, and J. Sempik, People, land and sustanability:Community gardens and the social dimension of sustainable development. Social Policy \& Administration, 2010.35(5):p.559-568.

5. Holland,L.,Diversity and connections in community gardens:A contribution to local sustainability.Local Environment, 2004.9(3):p.285-305.

6. Lawson, L., Cultural geographies in practice: The South central Farm: dilemmas in practicing the public. Cultural Geographies,2007. 14:p. 611-616

7. Macias,T., Working toward a just,equitable and locla food system: The social impact of communkty-based agricutlture. Social Science Quarterly, 2008.89:p.10861101.

8. Patel, I.C., Gardening's socioeconomic impacts. Journal of Extension,1991.29.

9. Shinew, K.J., T.D. Glover, and D.C. Parry, Leisure space as potential sites for interracial interaction:community gardens in urban areas. Journal of Leisure Research,2004.36:p.33-355.

10. Smit, J. and J.Nasr, Urban agriculture for sustainable cities:Using wastes and idle land and water bodies as resources. Environment and Urbanization, 1992.4:p.141152.

11. Pirog,R.,et al., Food, Fuel, and Freeways: An Iowa perspective on how far food travels, fuel usage, and greenhouse gas emissions, 2001, Leopold Centre for Sustainable Agriculture:Ames,Iowa. 